\title{
AIRCRAFT COLLISION PREDICTION BASED ON BINOMIAL DISTRIBUTION
}

\author{
Zvonko M. Radosavljevića , Branko D. Kovačevićb, \\ Dejan S. Ivkovićc \\ ${ }^{a}$ Military Technical Institute, Belgrade, Republic of Serbia, \\ e-mail: zvonko.radosavljevic@gmail.com, corresponding author, \\ ORCID iD: (i)https://orcid.org/0000-0003-0105-9103, \\ b University of Belgrade, School of Electrical Engineer, \\ Belgrade, Republic of Serbia, \\ e-mail: kovacevic_b@etf.rs, \\ ORCID iD: 『https://orcid.org/0000-0001-9334-9639 \\ ${ }^{a}$ Military Technical Institute, Belgrade, Republic of Serbia, \\ e-mail: divkovic555@gmail.com, \\ ORCID iD: (Dhttps://orcid.org/0000-0003-1517-7610
}

DOI: 10.5937/vojtehg68-25674; https://doi.org/10.5937/vojtehg68-25674

FIELD: Mathematics, Computer technology, Automatic control ARTICLE TYPE: Original Scientific Paper ARTICLE LANGUAGE: English

\begin{abstract}
:
Introduction/purpose: Based on the binomial distribution of the probability density function, a new probabilistic model for aircraft position predicting is presented in this paper.

Methods: The proposed algorithm is composed of three different blocks: Data Association, Tracking/Hybrid State Estimation and Calculation of Probability of Conflict. The information about aircraft current positions and flight plans is used to derive an algorithm for detecting possible conflicts between aircraft. The situations where aircraft may come closer than a certain distance to one another are predicted with high probability. The position estimate and indeterminacy refer to target association when two tracks fall in a validation region by using the Probabilistic Data Association Filter.

Results: An efficient collision detection algorithm is designed and tested for a lot of multiple target tracking.

Conclusion: The simulation results of aircraft conflict prevention in two trajectory scenarios verify the efficiency of the proposed algorithm.
\end{abstract}

Key words: automatic control, probability, target tracking, data association. 


\section{Introduction}

Air collision is an aviation accident category defined as a collision between aircraft in flight. The main aim of the air colision software tool under development is to analyse radar data in order to identify all proximate events (conflicts, potential conflicts, and potential collisions) within a volume of airspace and time span, to classify them according to various criteria into classes, to estimate the frequency of occurrence, and to calculate the different parameters needed to estimate the probability of aircraft being on a collision course and the probability of Air Traffic Control (ATC) loop resolution failure. The identification and analysis of potential conflicts is based on aircraft track association. Measurements in track association identify when an aircraft is turning, changing its vertical position or modifying its speed, so as to replace the full detailed track of each aircraft with a number of potential positions, from one scan to another.

Continued growth of air travel and recent advances in new technologies for navigation, surveillance, and communication has led to provide reliable and efficient tools to aid Air Traffic Control (ATC). The ATC system is responsible for safe air traffic operations of both commercial and military types. Standard multiple target tracking of wide band maneuvering aircraft is based on Track While Scan (TWS) radar data and Kalman filter processing (Blackman, 1986), (Challa et al, 2011).

To prevent aeroplane conflicts, many of Air Traffic Control (ATC) systems resort to a two part process. In the first part, conflict detection is performed by the following: the estimate positions of all aircraft which fall into a validation region in the future, based on their current positions and flight plan, are predicted, and they are compared so as to detect situations of conflict. Once a conflict has been detected, the trajectories of the aeroplanes involved in the conflict are re-planned in the conflict resolution part. Conflict detection and resolution is actually given consideration at three different levels of the ATC process, which differ in the Euclidian distance over which conflict detection and resolution is performed. They are Long Range (LR), Mid Range (MR), and Short Range (SR).

Many methods are used to ensure safe distance. Bayesian inference and Hierarchical structures are often used to develop statistical estimation and prediction models (Valdés et al, 2018). Some authors suggest a Brownian motion, in which the probability of conflict becomes the probability that a Brownian motion escapes from a time-varying safe region ( $\mathrm{Hu}$ et al, 1999). An extensive study is performed with a model 
introduced to predict the aircraft positions along some look-ahead time horizon, during which each aircraft is trying to follow a prescribed flight plan despite the presence of additive wind perturbations to its velocity. Based on the Markov chain aproximation, a method is introduced to evaluate the criticality of the encounter situation by estimating the probability of conflict, namely, the probability that the two aircraft come closer than a minimum allowed distance at some time instant during the look-ahead time horizon (Hu et al, 2005).

An algorithm, based on the Probabilistic Data Association Filter (PDAF) algorithm for LR and MR conflict detection is then proposed and its performances are compared by Monte Carlo simulations. The proposed algorithm is composed of three different blocks: Data Association, Tracking/Hybrid State Estimation and Calculation of Probability of Conflict. The improved results of conflict detection probability computation, using the PDAF method, are presented. The proposed algorithm computes the maximum likelihood for all measurements within the validation region, apropos the minimum statistic distance calculated from measurements (target-originated, clatter, false target-originated, etc.) within the gate and target estimate from the previous data sequence.

The paper is organized as follows: after the introductory remarks, the problem of formulation is given in Section 2. Section 3 presents the probabilistic data association filter which is the first step of the proposed algorithm. The description of the proposed conflict detection algorithm is presented in Section 4. Finally, the simulation results of two aircraft motion scenarios are presented in Section 5, which precedes the Conclusion Section.

\section{Problem formulation}

Let us assume that two aircraft are flying at the same altitude along the paths the intersection angle of which is time constant during flight and that the probability density of aircraft collision has the Gaussian distribution. The conflict detection algorithm in flight closeness of two aircraft, based on the PDA algorithm, is presented. The probability of conflict is calculated by the use of estimated states and weighting error covariance updates. Aircraft conflict prediction is determined for the duration of one radar scan, before aircraft collision. In our simulation, the safety time is $5 \mathrm{~s}$.

Regarding the validation gate, a safety region is formed beside the aircraft. This condition should be valid for the maximum speed of the 
conflict aircraft and the direction of vector speed of the observed aircraft. When the conflict aircraft enters the validation region of the observed aircraft, there is a probability of conflict of two neighboring aircraft at the sample time $k$. Contemplate the situation for two aircraft flying at the same altitude.

The problem considered is that of tracking a single target in clutter, when the retrieval of two measurements fall in the validation gate. The linear dynamical target state model is given by the following:

$$
\begin{gathered}
x(k)=F \cdot x(k-1)+G \cdot w(k-1) \\
y(k)=H \cdot x(k)+v(k)
\end{gathered}
$$

where $F, G, H$ are the known matrices, $w(k)$ and $v(k)$ are independent, zero-mean, white Gaussian noise processes with the covariance $Q(k)$ and $R(k)$, respectively. At the time $k$, a set of $m(k)$ measurements $\mathbf{Y}(k)=\left\{y_{i}(k)\right\}_{i=1}^{m(k)}$ is detected, where each measurement either originates from one of $n$ known linear measurement models or is a false detection, where $v(k)$ is a white, zero-mean Gaussian sequence with the known covariance $R(k)$. The sequences $v(k)$ are mutually independent and uncorrelated with the process noise $w(k)$.

\section{Probabilistic data association filter}

The PDAF is a suboptimal Bayesian algorithm that associates probabilistically all the validated measurements to the target of interest (Blackman, 1986), (Challa et al, 2011).

The PDAF method associates each validated measurement probabilistic to the estimated track (Reid, 1979).

The case with two measurements in each radar scan is presented (Fig. 1). Prediction computation is necessary for each target-originated measurement, but only one measurement is the target.

The PDAF method assumes that there is only one target of interest whose track has already been initialized.

The basic assumption is the normally distributed filter state according to the latest estimates and the covariance matrix, and the overall state of estimates and covariance is given by the weighted average of all the measurements falling within the validation gate of the target. 


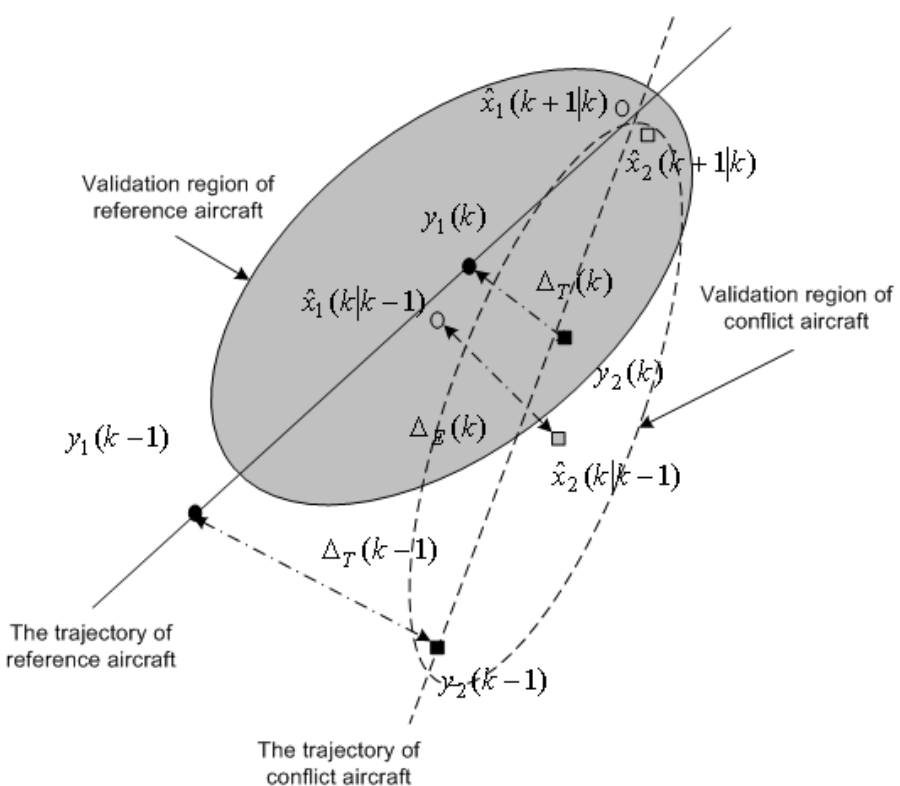

Figure 1 - Illustration of the PDAF with two measurements within the validation gate Puс. 1 - Иллюстрация фольттра для идентификации данных по вероятности (PDAF) с двумя измерениями внутри подтвержденного окна Слика 1 - Илустрација фолтра за придруживање података по вероватноћи (PDAF) са два мерења унутар потврђеног прозора

Assume that we have measurements at the sample time $k$. We denote this set of measurements and the set of all cumulative sets up to the time $k$, by the following assemblies, respectively (Bar-Shalom \& Tse, 1975):

$$
\begin{aligned}
& Y(k)=\left\{y_{1}(k), y_{2}(k), \ldots, y_{m(k)}\right\} \\
& \mathbf{Y}(k)=\{Y(k), Y(k-1), \cdots, Y(0)\}
\end{aligned}
$$

Whence, the estimation of the Probabilistic Data Association method is based on the latest set of measurements. The assembly of all possible events, at the sample time $k$, can be considered as two, mutually exclusive and exhaustive events:

$\mathrm{H}_{0}(k)$ - none of measuremenst originated from the target

and

$H_{1}(k)-i^{\text {th }}-$ mesurement is the target originated 


$$
H_{i}(k)=\left\{H_{0}(k), H_{1}(k)\right\}=\left\{\begin{array}{l}
H_{0}(k), \quad i=0 \\
H_{1}(k), \quad i=1,2, \ldots, m(k)
\end{array}\right.
$$

with the probabilities:

$$
p_{i}(k)=P_{r}\left\{H_{i}(k) \mid \mathbf{Y}(k)\right\}=\left\{\begin{array}{l}
p_{0}(k)=P_{r}\left\{H_{0}(k) \mid \mathbf{Y}(k)\right\}, \quad i=0 \\
p_{1}(k)=P_{r}\left\{H_{1}(k) \mid \mathbf{Y}(k)\right\}, \quad i=1,2, \ldots, m(k)
\end{array}\right.
$$

Explicitly, $p_{0}(k)+p_{1}(k)=1$. The estimate is calculated using the total probability theorem:

$$
\hat{x}(k \mid k)=E\{x(k) \mid \mathbf{Y}(k)\}=\sum_{i=0}^{m(k)} E\left\{x(k), H_{i}(k), \mathbf{Y}(k)\right\} p_{i}(k)=\sum_{i=0}^{m(k)} x_{i}(k) p_{i}(k)
$$

where $x_{i}(k)$ is the update state conditioned on the event $H_{i}(k)$ that $y_{i}(k)$ is the corect mesurement. From the Kalman filter, we have (BarShalom \& Fortmann, 1988):

$$
\begin{gathered}
x_{i}(k \mid k)=\hat{x}(k \mid k-1)+K(k) r_{i}(k) \\
r_{i}(k)=y_{i}(k)-h \cdot x_{i}(k \mid k-1)
\end{gathered}
$$

where is the Kalman gain $K(k)$, and the residual of innovation $r_{i}(k)$ at the time $k$. After combining prior equations, get the update state:

$$
\hat{x}(k \mid k)=\hat{x}(k \mid k-1)+K(k) r(k)
$$

And the weighted sum of residuals:

$$
r(k)=\sum_{i=0}^{m(k)} p_{i}(k) r_{i}(k)
$$

The error covariance matrix is updated as: 


$$
P(k \mid k)=p_{0}(k) P(k-1)+\left(1-p_{0}(k)\right) P^{c}(k \mid k)+\widetilde{P}(k \mid k-1)
$$

where $P^{c}(k \mid k)$ is given by:

$$
P^{c}(k \mid k)=[I-K(k) H(k)] P(k-1)
$$

and where $\widetilde{P}(k \mid k)$ is given by:

$$
\widetilde{P}(k \mid k)=K(k)\left[\sum_{i=1}^{m(k)} p_{i}(k) r_{i}(k)\left(r_{i}(k)\right)^{\prime}-r(k) r(k)\right] K^{\prime}(k)
$$

The final step is combining the model-conditioned state estimate and the covariance, according to the following equations:

$$
\hat{x}(k \mid k)=\sum_{i=0}^{m_{k}} \alpha_{i}(k) \hat{x}_{i}(k \mid k)
$$

where $\alpha_{i}(k)$ is the association probability of the measurement $y_{i}(k)$, and $x_{i}(k \mid k)$ is the estimate associated with the $i^{\text {th }}$ measurement and $\hat{x}(k \mid k)$ is the overall estimate. The association probability in the proposed algorithm is calculated by (Radosavljević \& Mušicki, 2011):

$$
\alpha_{i}(k)= \begin{cases}\frac{c(k)}{c(k)+\sum_{i=1}^{m(k)} b_{i}(k)}, & i=0 . \\ \frac{b_{i}(k)}{c(k)+\sum_{i=1}^{m(k)} b_{i}(k)}, & i=1,2, \ldots, m(k)\end{cases}
$$

where $c(k)=\frac{m(k)\left(1-P_{D} P_{G}\right)}{P_{D} P_{G} V(k)}$ and $b_{i}(k)=\frac{1}{P_{G}} N\left[r_{i} ; 0, S(k)\right]$, $P_{D}$ is the probability of detection, $P_{G}$ is the probability that a measurement falls within the gate, $V(k)$ is the validation region, $N(x ; \mu ; S)$ is the Gaussian noise process with means $\mu$ and varinces $S$, 
$r_{i}(k)$ is the innovation, and $S$ is the innovation covariance (Bar-Shalom \& Dale Blair, 2000).

\section{Measurement validation and gating}

A technique, which is sometimes called gating or measurement within a validation region, is able to select which measurement should be associated to the existing track. This track is our airplane. If we assume that we already have one track and we receive new measurements, we can assume that, in order to be able to associate measurements to the track, they must be in the vicinity of the predicted track.

Thus, the validation procedure is able to use the residual from the $i^{\text {th }}$ measurement, the track $r_{i}(k)$, and the innovation covariance $\mathrm{S}$. The distance from the $i^{\text {th }}$ measurement to the predicted position of the track is calculated by (Hwang et al, 2003b):

$$
d_{i}^{2}(k)=r_{i}^{T}(k) S^{-1} r_{i}(k)
$$

We assume that before tracking is started, the gate probability $P_{G}$ has been determined. We are able to obtain a quantity $V_{i}(k)$, using the $P_{G}$ and $\chi^{2}$-tables. The probability density function of target measurement is then given by the following expression

$$
V_{i}(k)=\frac{e^{-\frac{d_{i}^{2}(k)}{2}}}{2 \pi \sqrt{|S|}}
$$

where $V_{i}(k)$ is a threshold such that $d_{i}<V_{i}$.

\section{Aircraft conflict detection algorithm}

\section{Binomial distribution of aircraft conflict probability}

The binomial probability distribution first considers Bernoulli. A Bernoulli trial has only two outcomes - success or failure. To begin, assume $C$ and $\bar{C}$ are two mutually independent, exclusive and exhaustive trials which happen at the either sample time, respectively, by the following (Gad et al, 2004): 


$$
\left\{\begin{array}{lll}
P_{r}\{C \mid \mathbf{Y}(k)\}=\pi(k) & \text { - conflict } & \text { will occur } \\
P_{r}\{\bar{C} \mid \mathbf{Y}(k)\}=1-\pi(k) & \text { - conflict } & \text { will not occur }
\end{array},\right.
$$

If the total number of successes of both trials before the sample time $\mathrm{k}$ is $n^{(k)}$, then the probability that the trial $\pi(k)$ is repeated $l^{(k)}$ times is given by the following equation

$$
P_{r}\left\{C=l^{(k)} \mid \mathbf{Y}(k)\right\}=\pi(k)^{l^{(k)}} \cdot[1-\pi(k)]^{n^{(k)}-l^{(k)}}
$$

The appropriate distribution of probability is denominated binomial distribution given by:

$P_{r}\{C, \bar{C} \mid \mathbf{Y}(k)\}=\sum_{l^{(k)}=0}^{n^{(k)}}\left(\begin{array}{l}n^{(k)} \\ l^{(k)}\end{array}\right) \cdot \pi(k)^{l^{(k)}} \cdot(1-\pi(k))^{n^{(k)}-l^{(k)}} \cdot \delta(k-l)$

Therefore, the probability density function (pdf) of binomial distribution is given by the following:

$$
\operatorname{pdf}\left(l^{(k)} ; n^{(k)}\right)=\frac{n^{(k)} !}{n(k) ! \cdot\left[n^{(k)}-l^{(k)}\right] !} \cdot \pi(k)^{l^{(k)}} \cdot[1-\pi(k)]^{n^{(k)}-l^{(k)}}
$$

is satisfying the total probability theorem, given in the formula. In general, the mean and the variance of a binomial distribution with the parameters $n^{(k)}$ and the probability of success $\pi(k)$ are given by the following equations (Karlsson, 2002):

$$
\begin{gathered}
\mu_{N}(k)=n^{(k)} \cdot \pi(k) \\
\sigma(k)^{2}=n^{(k)} \cdot \pi(k) \cdot[1-\pi(k)]
\end{gathered}
$$

respectively.

\section{Conflict detection approach}

Suppose $y_{0}(k), y_{1}(k)$ are the measurements originating from the conflict and the observed aircraft arriving during the sample time, respectively. The true distance between the observed aircraft and the conflict one can be defined as absolute difference $\left|y_{0}(k)-y_{1}(k)\right|$. Based on the true distance of the two aircraft, we can define the true probability of conflict as the relative ratio of safety distance and true position distance, which is given in the following (Bar-Shalom \& Li, 1999): 


$$
\sigma(k)^{2}=n^{(k)} \cdot \pi(k) \cdot[1-\pi(k)]
$$

Similarly, if $\hat{x}_{0}(k \mid k-1), \hat{x}_{1}(k \mid k-1)$ are the estimate positions of the conflict and observed aircraft, we can define the estimate position distance as the absolute difference $\left|\hat{x}_{0}(k \mid k-1)-\hat{x}_{1}(k \mid k-1)\right|$. On the other hand, in the theory of aircraft conflict, it is necessary to satisfy the condition of safe statistical distance: $0 \leq d_{i}^{2}(k) \leq \varepsilon$. Then the estimate probability of conflict $p_{E}(k)$ is defined by the relative ratio of the known parameter $\varepsilon_{s}$-safety distance and estimate position distance:

$$
p_{E}(k \mid k-1)=\frac{\varepsilon_{S}}{\left|\hat{x}_{0}(k \mid k-1)-\hat{x}_{1}(k \mid k-1)\right|}
$$

where $y_{1}(k), y_{2}(k)$ are the measurements (from the set of all new measurements in the time step $k$ ) fall in the validation region and $\hat{x}_{0}(k \mid k-1), \hat{x}_{1}(k \mid k-1)$ are the analogous estimate positions of measurements, at the sample time $k$. So, let us define the bound of safety as a dimension of the validation region after which the probability of conflict will have a value of one. The quantity $d_{i j}^{2}(k)$ is the sum of the squares of two independent Gaussian random variables with zero means and unit standard deviations. For that reason, $d_{i j}^{2}(k)$ will have the $\chi_{2}^{2}$ distribution for correct observation-to-track pairings with the $M$ degrees of freedom and allowable probability $P=1-P_{d}$ of a valid observation falling outside the gate, where $P_{d}$ is the probability for correct detection. The threshold constant $V_{i j}$ can be defined from the table of the $\chi_{2}^{2}$ distribution with two degrees of freedom and allowable probability of a valid observation falling outside the gate (Bar-Shalom \& Fortmann, 1988).

From equations (16), (19), and the assumed $m(k)$ measurements, the overall probability density of conflict, for the overall case, if the validation region is within the interval $0 \leq d_{i}^{2}(k) \leq+\propto$, at the sample time $k$, is given by the following equation:

$$
p_{C}(k \mid k-1)=P_{r}\left\{H_{i}(k) \mid \mathbf{Y}(k-1)\right\} \cdot P_{r}\{C, \bar{C} \mid \mathbf{Y}(k-1)\}, \quad i=0,1, \ldots, m(k)
$$

It is clearly seen that: 


$$
p_{C}(k \mid k-1)= \begin{cases}0, & i=0 \\ 1, & i=1,2 \ldots, m(k)\end{cases}
$$

Finally, after the evolution of the previous equation per all possible hypotheses and assumed "success trials" when position estimates fall in the safety region, we obtain the following (Hwang et al, 2003):

$$
\begin{aligned}
& p_{C}(k \mid k-1)=
\end{aligned}
$$

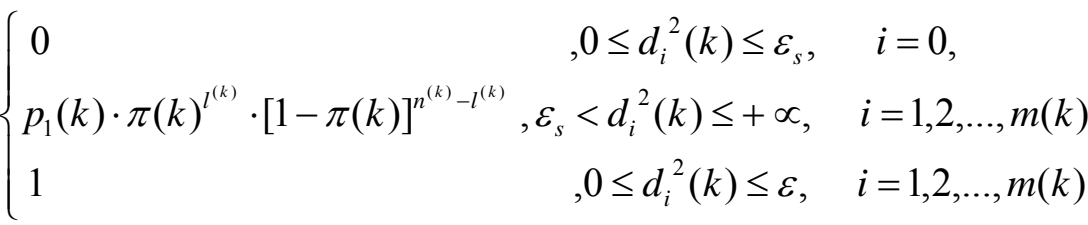

where $d_{i}^{2}(k)$ is the distance for the $i^{\text {th }}$ measurement to the predicted position of the track, $p_{1}(k)$ is the probability given by $(6)$ and:

$$
\pi(k)=P_{r}\{C \mid \mathbf{Y}(k)\}=p_{E}(k \mid k-1)
$$

A numerical example: We assumed binomial probability distribution of the third order, with $n=3$, given by the following (Hwang, 2003):

$$
\begin{aligned}
& P_{r}(C, \bar{C} \mid \mathbf{Y}(k))= \\
& =\sum_{l^{(k)}=0}^{3}\left(\begin{array}{l}
3 \\
l^{(k)}
\end{array}\right) \pi^{l^{(k)}}(1-\pi)^{n^{(k)}-l^{(k)}}= \\
& =\pi^{3}+3 \pi^{2}(1-\pi)+3 \pi(1-\pi)^{2}+(1-\pi)^{3}=1
\end{aligned}
$$

where:

$$
\pi(k)=\operatorname{Pr}\{C \mid \mathbf{Y}(k)\}=0.5
$$

The graphs of the probability density function at binomial distribution, for the total number of observed time intervals $n^{(k)}=1,2, \ldots, 10$ and with the probabilities of events $\pi(k)=0.25, \pi(k)=0.5 \pi(k)=0.75$ are given in Fig. $2 \mathrm{a}$. The binomial distribution of probability with the number of observed time sequences and with a variety of probabilities of trials is given in Fig. $2 b$. 


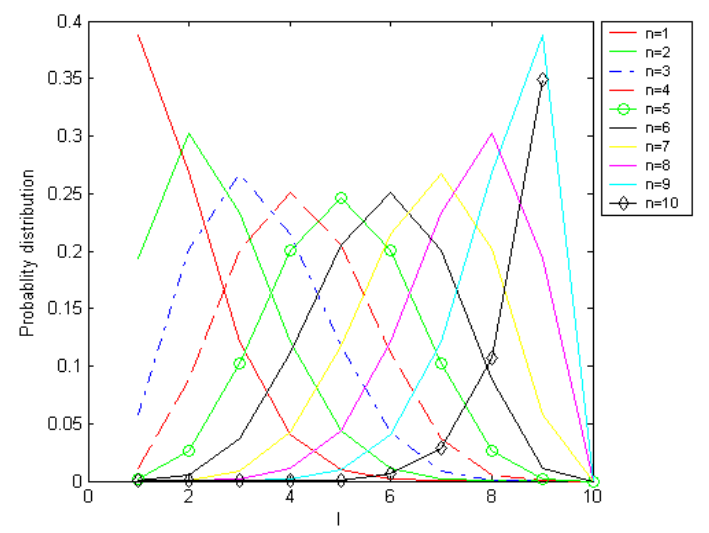

a) Binomial distribution of probability, with the number of time intervals $n^{(k)}=1,2, \ldots, 10$, b) 3D-binomial distribution of probability, with the number of observed time sequences and probabilities of trials

$$
\text { Puc. } 2 \text { - }
$$

а) Биномиальное распределение вероятностей с количеством временных интервалов $n^{(k)}=1,2, \ldots, 10$,

б) Трехмерное биномиальное распределение вероятностей с количеством наблюдаемых временных последовательностей и вероятностей событий Слика 2 -

а) Биномна расподела вероватноће са бројем временских интервала

$$
n^{(k)}=1,2, \ldots, 10,
$$

б) Тродимензионална биномна расподела вероватноће са бројем посматраних временских низова и вероватноћама догађаја 


\section{Simulation results}

The performances of the implemented tracking filters and the corresponding neural network method are evaluated by Monte Carlo $(M C)$ simulations over several representative test trajectories. The measure of performance is done using the Root Mean Square Error (BarShalom \& Li, 1999):

$$
R M S E(k)=\sqrt{\frac{1}{N_{M C}} \sum_{i=1}^{N_{M C}}\left(\hat{\xi}^{i}(k)-\xi^{i}(k)\right)^{2}+\left(\hat{\eta}^{i}(k)-\eta^{i}(k)\right)^{2}}
$$

where $\hat{\xi}^{i}(k), \hat{\eta}^{i}(k)$ are the position estimates (Cartesian coordinates) at the discrete time $k$, in $M C$ run $i$ and $\xi^{i}(k), \eta^{i}(k)$ are the measurement results. In the beginning, we assumed that both aircraft can have constant velocity $(C V)$ or be in the coordinate turn $(C T)$ mode (Fitzgerald, 1990). The tracking of two aircraft which interact in a period of time, is considered in this section. The observed aircraft is called the reference aircraft. The second aircraft, which enters the validation region of the reference aircraft, is called the stochastic aircraft. In order to test the efficiency of the proposed algorithm, two types of aircraft trajectories are formed. The first trajectory is without maneuver while the second trajectory has a maneuver with $g$ acceleration. The test trajectories involve two aircraft flying along straight lines at an equal speed of 311 $\mathrm{m} / \mathrm{s}$. The flight data come from a radar sensor with a sampling interval $T=5 \mathrm{~s}$. The duration of both simulations is 72 scans.

In the first test scenario, given in Fig. 3a, the reference aircraft is moving rectilinearly at a constant speed of $311 \mathrm{~m} / \mathrm{s}$ and at an angle of $45^{\circ}$ in relation to the origin. The conflict aircraft performs full turn maneuvers with the intensities of $g, 2 g, g$ and $3 g$ during the scans 10-28, 37-45, 55-58, and 65-73, respectively.

The second test scenario, given in Fig. $3 \mathrm{~b}$, presents the trajectories of two aircraft at a constant speed of $311 \mathrm{~m} / \mathrm{s}$. The targets move towards each other. The first target is the reference aircraft flying towards the radar along the 45-degree line to the north while the trajectory of the second target (the conflict aircraft) is mirroring the first trajectory. At $k=34^{\text {th }}$ scan, both targets executed constant speed turns, of magnitude $g$ that lasted for $k=8$ scans. During the maneuvers, the trajectories intersected and after the completions of the maneuvers, both targets 
continued to move at constant speed. The radar is located at the origin, and cannot be shown. The trajectories from test scenario 1 intersected during scan 32, while the trajectories from test scenario 2 intersected during scan 44 .

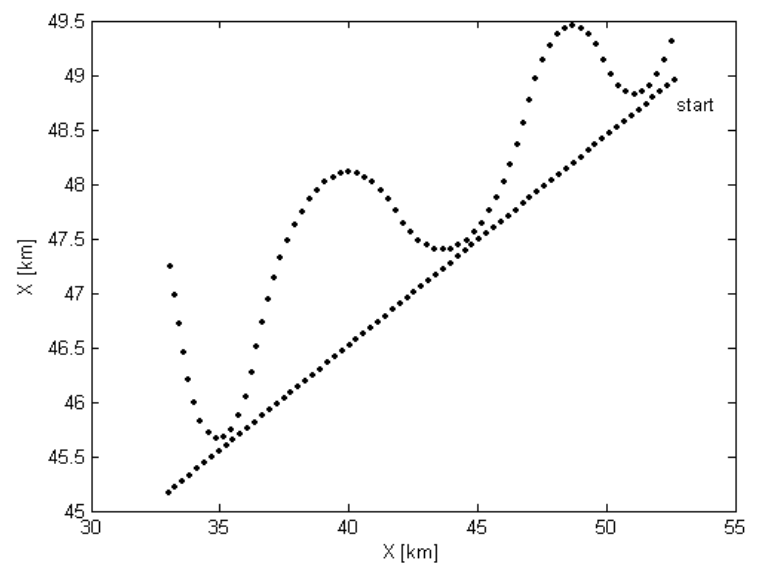

a)

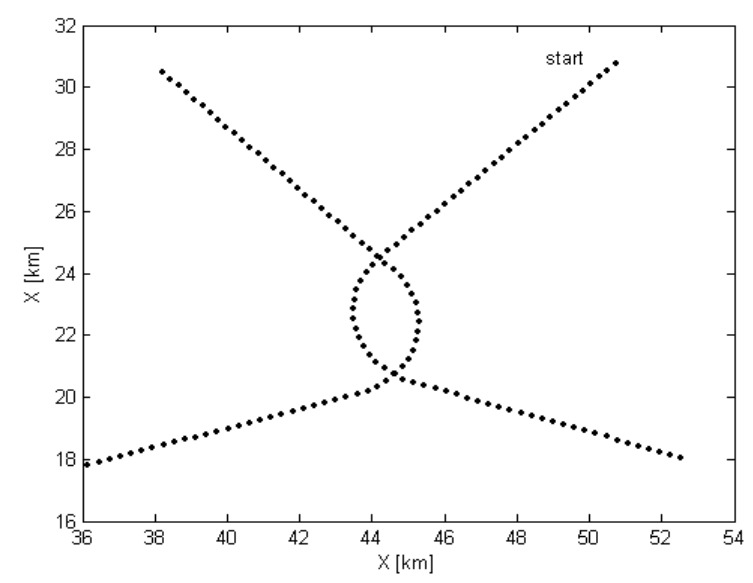

b)

Figure $3-$ a) Trajectories from test scenario 1, and b) trajectories from test scenario 2

Puc. 3 - а) Траектории из тестового сценария 1 б) траектории из тестового сценария 2

Слика 3 - а) Трајекторије из тест-сценарија 1 и б) трајекторије из тест-сценарија 2 


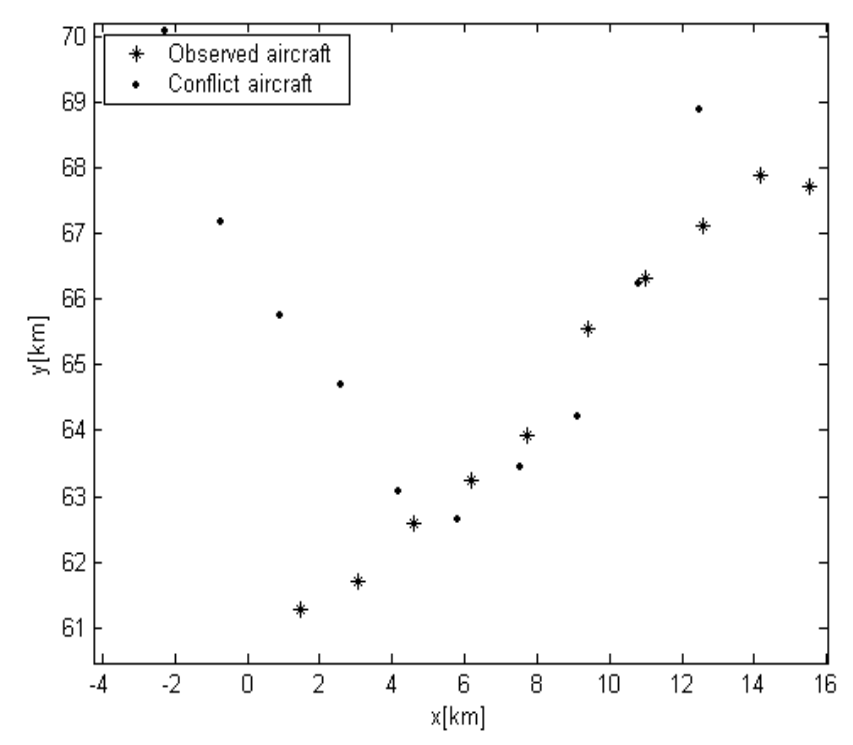

a)

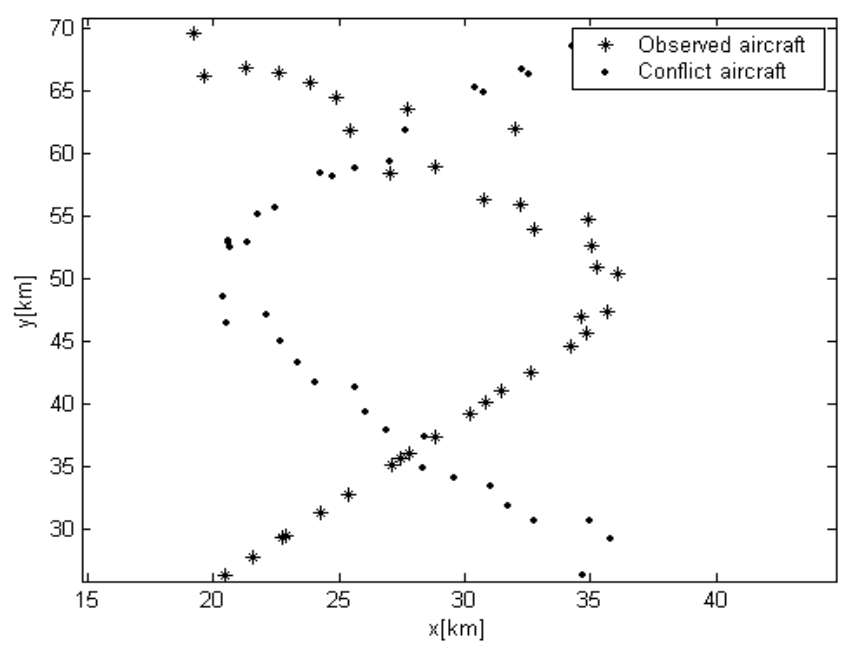

b)

Figure 4 - Approaching the conflict in a) test scenario 1 and b) test scenario 2 Puc. 4 - Приближение столкновений в

a) тестовом сценарии 1 и б) тестовом сценарии 2

Слика 4 - Приближавање судара у а) тест-сценарију 1 и б) тест-сценарију 2 
Consider the target moving in two dimensions, with two dynamic models and with process noise. For both trajectories, the constant velocity $(\mathrm{CV})$ model is used, with the state vector defined as $\mathbf{x}(k)=\left[\begin{array}{llll}x & \dot{x} & y & \dot{y}\end{array}\right]^{\prime}$. The matrices $\mathbf{F}_{c v}$ and $\mathbf{H}$ are defined by the equations:

$$
\mathbf{F}_{C V}=\left[\begin{array}{cccc}
1 & T & 0 & 0 \\
0 & 1 & 0 & 0 \\
0 & 0 & 1 & T \\
0 & 0 & 0 & 1
\end{array}\right], \mathbf{H}_{C V}=\left[\begin{array}{cccc}
1 & 0 & 0 & 0 \\
0 & 0 & 1 & 0
\end{array}\right]
$$

respectively, where $q=0.2$, is the maneuver parameter (Song et al, 2012):

$$
\mathbf{Q}(k)=q\left[\begin{array}{cccc}
T^{3 / 3} & T^{2} / 2 & 0 & 0 \\
T^{2} / 2 & T & 0 & 0 \\
0 & 0 & T^{3 / 3} & T^{2} / 2 \\
0 & 0 & T^{2} / 2 & T
\end{array}\right], \quad \mathbf{R}=\left[\begin{array}{cc}
\sigma_{x}^{2} & 0 \\
0 & \sigma_{y}^{2}
\end{array}\right]
$$

where $\sigma_{x}=\sigma_{y}=20 \mathrm{~m}$. The choice of the model set is of vital importance and must compromise computational load and target modeling flexibility. It has been found that the following two models: the constant velocity $(\mathrm{CV})$ model (obtained for angular speed $\omega_{0}=0$ ) and the coordinated turn (CT) model (obtained for angular speed $\omega_{0}>0$ ), provide an adequate and self-contained model set for tracking purpose.

The conflict probability distributions for test scenario 1 and test scenario 2 are given in Figs. $5 a$ and $5 b$, respectively. The time distributions of conflict prediction for the third-order binomial distribution for test trajectory 1 and test trajectory 2 are given in Figs. $6 a$ and $6 \mathrm{~b}$. Similarly, the time distribution of conflict prediction for the fifth-order binomial distribution for test trajectories 1 and 2 are given in Figs. 7a and $7 b$. 


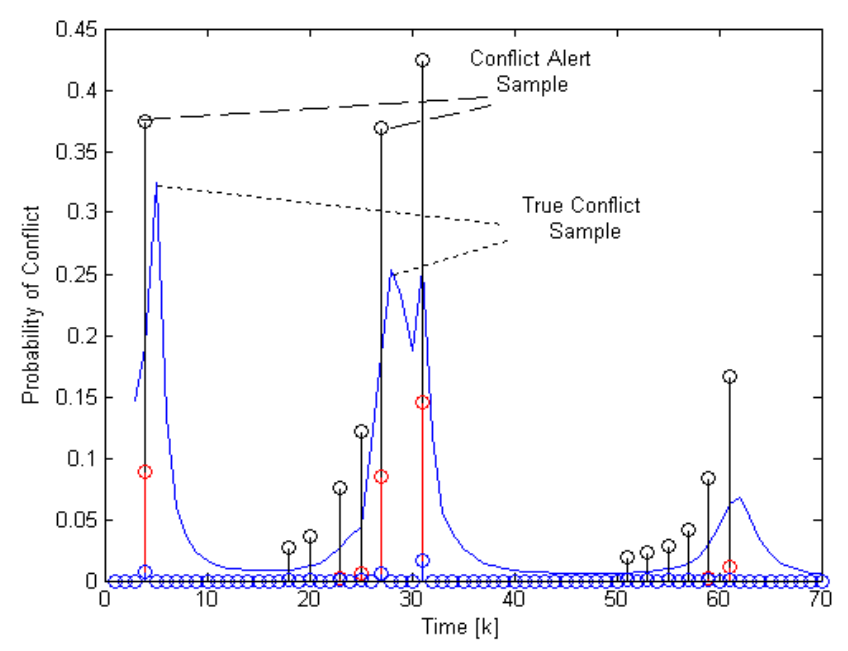

a)

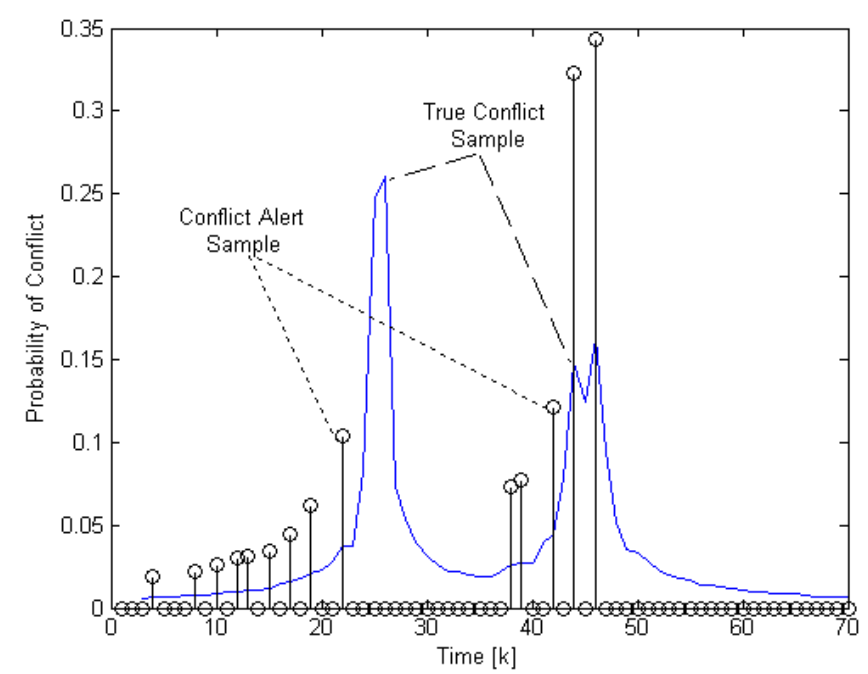

b)

Figure 5 - Time distributions of conflict probability at the noise variance $\sigma^{2}=0.04$ a) test scenario 1 and b) test scenario 2

Puc. 5 - Временные распределения вероятности столкновений при дисперсии шума

a) тестовый сценарий 1 и б) тестовый сценарий 2

Слика 5 - Временска расподела вероватноће судара при дисперзији шума $\sigma^{2}=0.04$, а) тест-сценарио 1 и б) тест-сценарио 2 


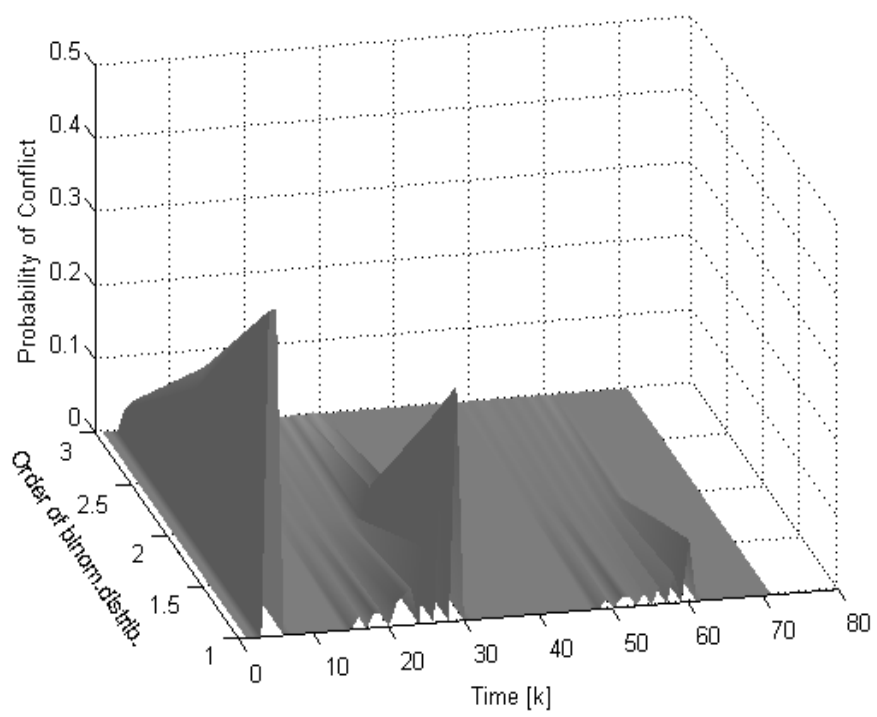

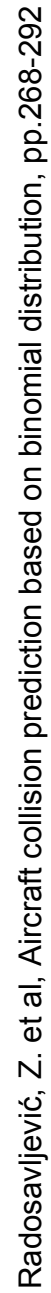

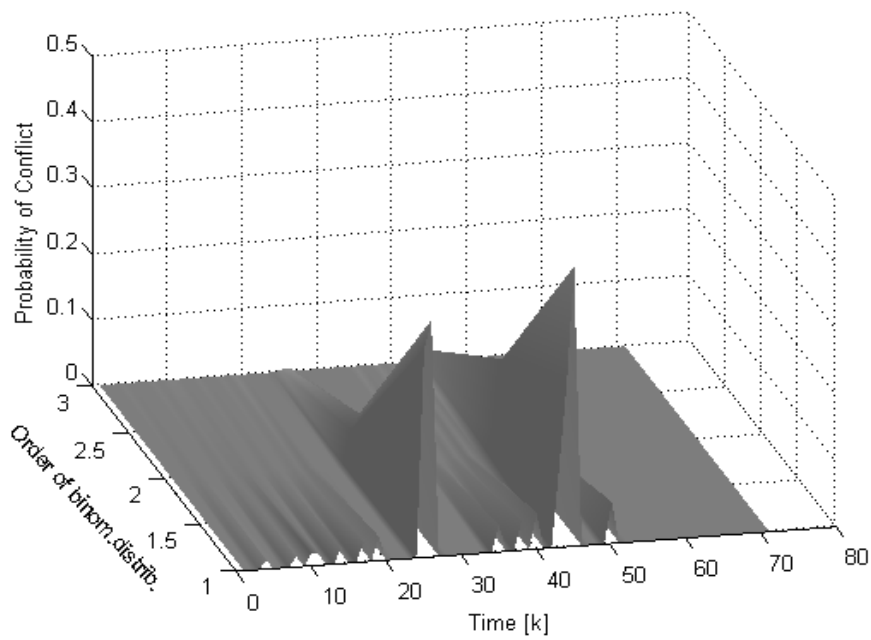

b)

Figure $6-3 D$ conflict probability at the 3rd-order binomial distribution a) test scenario 1 and b) test scenario 2

Puc. 6 -Трехмерная вероятность столкновения при биномиальном распределении 3-го ряда

Слика 6 - Тродимензионална вероватноћа судара у биномној расподели 3. реда 


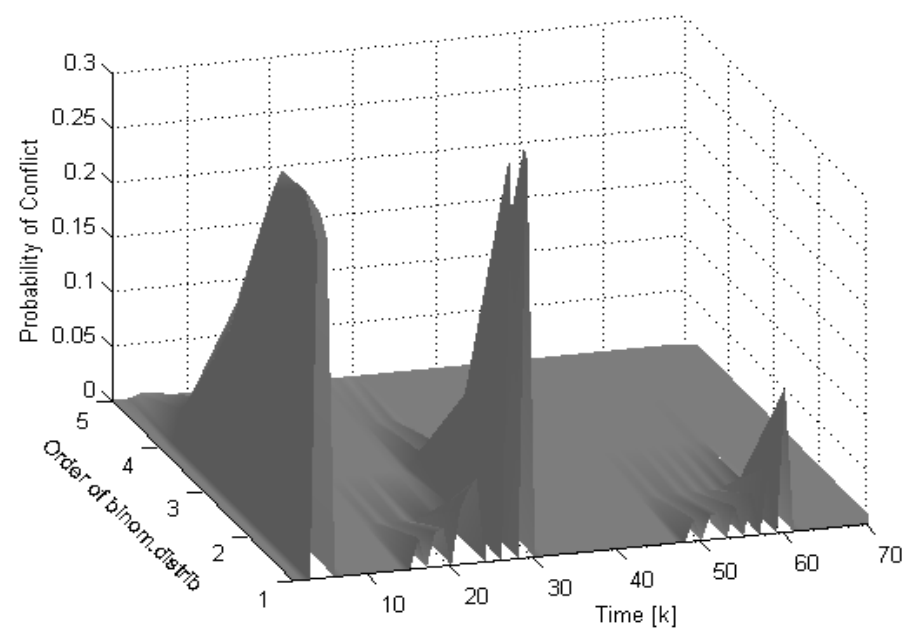

a)

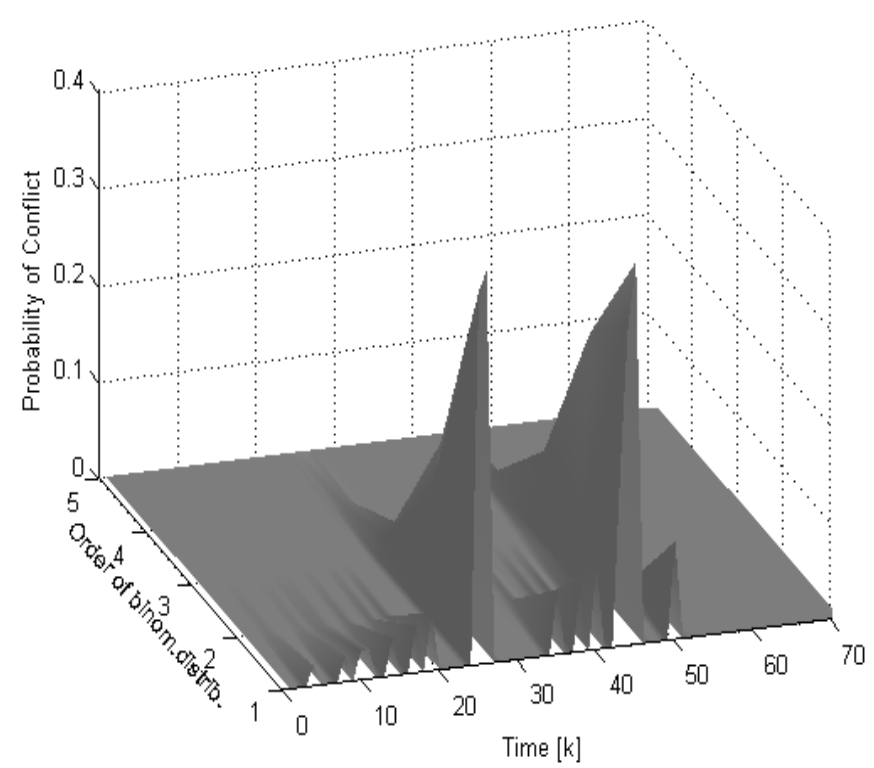

b)

Figure $7-3 D$ conflict probability at the 5th-order binomial distribution a) test scenario 1 and b) test scenario 2

Puc. 7 - Трехмерная вероятность столкновения при биномиальном распределении 5-го ряда

Слика 7 - Тродимензионална вероватноћа судара у биномној расподели 5. реда 

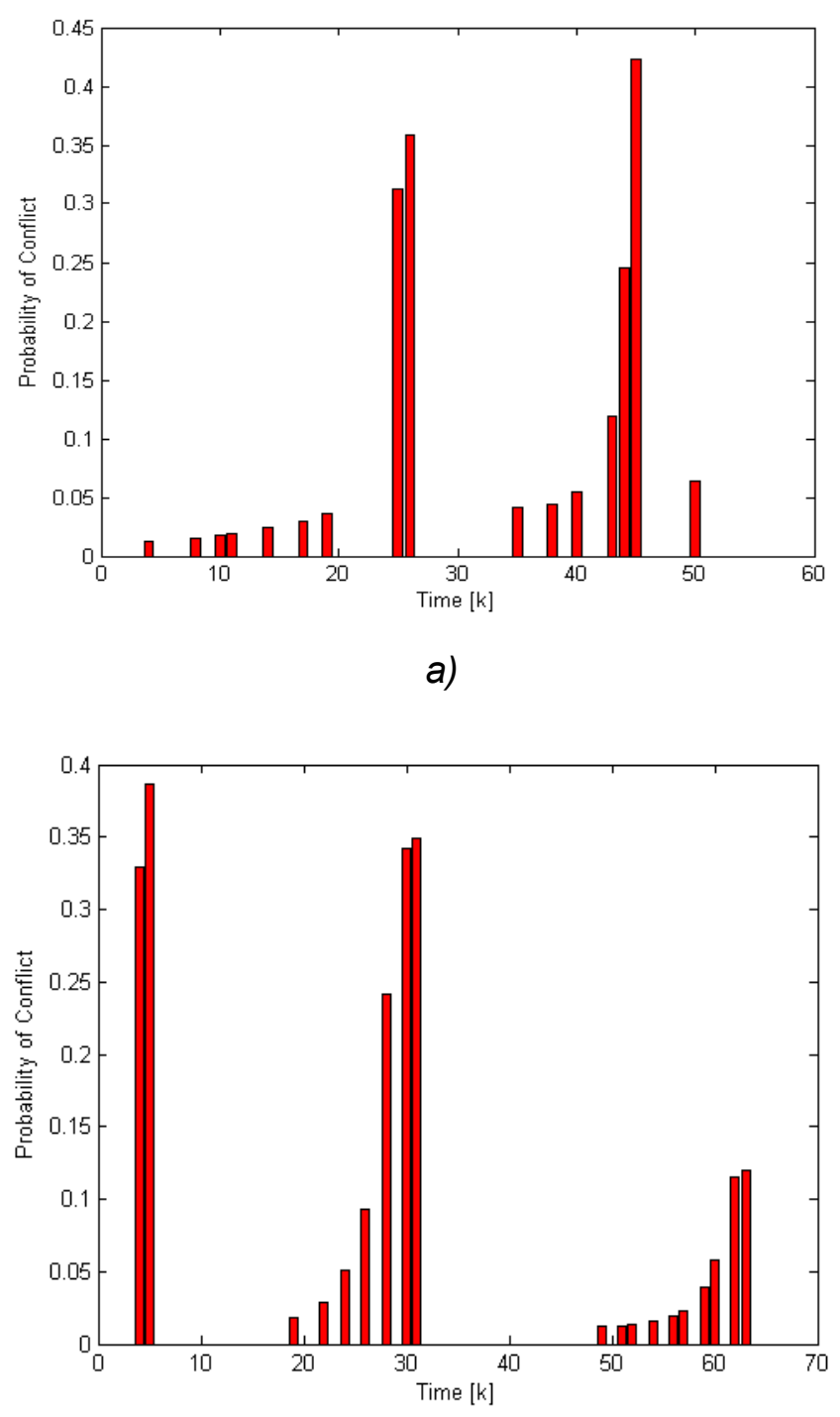

b)

Figure $8-2 D$ distributions of conflict probability at the noise variance $\sigma^{2}=0.02$ a) test scenario 1 and b) test scenario 2

Pис. 8 - Распределение вероятности столкновения при дисперсии шума $\sigma^{2}=0.02$ а) тестовый сценарий 1 и б) тестовый сценарий 2

Слика 8 - Расподела вероватноће судара при варијанси шума $\sigma^{2}=0.02$, а) тест- сценарио 1 и б) тест-сценарио 2 
The simulations results validate the probability data association algorithm, incorporated in the conflict detection method, and achieve good balance within two trajectories of flight. Finally, it could be easily observed that the conflict probability function rapidly increases into the validation region. The algorithm could be used to detect a conflict early enough to take a safe resolution maneuver if a neighboring aircraft starts a maneuver which might cause a conflict.

\section{Conclusion}

A new aircraft collision algorithm, by the use known PDAF algorithm, based on binomial distribution is presented in this paper. The common approach is calculating probabilities of all possible label-target assignments at each time step in the system. In that sense, we develop a probabilistic methodology, using track data association which can efficiently compute conflict probability. The proposed algorithm can detect a conflict early enough to take a safe resolution maneuver. For the track data association process, we proposed the PDA filter. In order to compute a function of conflict probability, we have constructed an algorithm based on binomial distribution which considers information about previously estimated states of positions. Based on the PDAF probability, the ATC system is able to send an alarm to the aircraft during a sampling interval.

For safety verification, we needed to apply the proposed algorithm to other types of radar sensors with a sampling interval shorter than the sampling interval of TWS radar sensors. Also, we will test the proposed method using other algorithms for hybrid estimation and data association such as IMMJPDA (de Feo et al, 1997), (Paielli \& Erzberger, 2012), MHT (Nolan, 1998) or IMMPDAF.

\section{References}

Bar-Shalom, Y., \& Dale Blair, W. 2000. Multitarget multisensor tracking: applications and advanced, Volume 3. Norwood, MA: Artech House.

Bar-Shalom, Y., \& Fortmann, T.E. 1988. Tracking and Data Association, San Diego, CA: Academic Press.

Bar-Shalom, Y., \& Li, X., 1999. Multitarget-multisensor tracking: principles and techniques. Norwood, MA: Artech House.

Bar-Shalom, Y., \& Tse, E. 1975. Tracking in a Cluttered Environment with Probabilistic Data Association. Automatica, 11(5), pp.451-460. Available at: https://doi.org/10.1016/0005-1098(75)90021-7. 
Blackman, S. 1986. Multiple-target tracking with radar applications. Dedham, MA: Artech House.

Challa, S., Morelande, M.R., Mušicki, D., \& Evans, R. 2011. Fundamentals of Object Tracking. Cambridge, UK: Cambridge University Press.

de Feo, M., Graziano, A., Migliolo, R., \& Farina, A. 1997. IMMJPDA versus MHT and Kalman filter with NN correlation: performance comparison. In: IEE Proceedings - Radar, Sonar and Navigation, 144(2), pp.49-56. April. Available at: https://doi.org/10.1049/ip-rsn:19970976.

Fitzgerald, R.J. 1990. Development of practical PDA logic for multitarget Multisensor tracking by microprocessor. In: Bar-Shalom, Y. (Ed.) MultitargetMultisensor Tracking: Applications and Advances. Norwood, MA: Artech House, pp.1-23.

Gad, A., Farooq, M., Serdula, J., \& Peters, D. 2004. Multitarget tracking in a multisensor multiplatform environment. In: Proceedings of the 7th International Conference on Information Fusion, Stockholm, Sweden, June 28 to July 1 [online]. Available at: http://www.fusion2004.foi.se/papers/IF04-0206.pdf.

Hu, J., Lygeros, J., Prandini, M. \& Sastry, S. 1999. Aircraft conflict prediction and resolution using Brownian Motion. In: Proceedings of the 38th Conference on Decision \& Control, Phoenix, Arizona USA, pp.2438-2443, December [online]. Available at: https://people.eecs.berkeley.edu/ sastry/pubs/OldSastryALL/HuAircraftConflict1999.pdf [Accessed: 26 April 2020].

Hu, J., Prandini M. \& Sastry, S. 2005. Aircraft conflict prediction in the presence of a spatially correlated wind field. IEEE Transactions on Intelligent Transportation Systems, 6(3), pp.326-340. Available at: https://doi.org/10.1109/TITS.2005.853699.

Hwang, I. 2003. Air traffic surveillance and control using hybrid estimation and protocol based conflict resolution. PhD thesis. Stanford University.

Hwang, I., Hwang, J., \& Tomlin, C. 2003. Flight-mode-based aircraft conflict detection using a Residual-Mean interacting multiple model algorithm. In: Proceedings of the AIAA Guidance, Navigation, and Control Conference, Austin, Texas, August 11-14. Available at: https://doi.org/10.2514/6.2003-5340.

Karlsson, R. 2002. Simulation based methods for target tracking. Licentiate thesis. Linköping University [online]. Available at: http://www.divaportal.org/smash/record.jsf?pid=diva2\%3A250444\&dswid=-2785. [Accessed: 21 January 2020].

Nolan, M.S. 1998. Fundamentals of Air Traffic Control. Springer, The Wadsworth \& Brooks/Cole Mathematics Series, 3rd edition.

Paielli, R.A., \& Erzberger, H. 2012. Conflict probability estimation for free flight. Journal of Guidance, Control and Dynamics, 20(3), pp.588-596. Available at: https://doi.org/10.2514/2.4081.

Radosavljević, Z., \& Mušicki, D. 2011. Limits of target tracking in heavy clutter. In: Proceedings ASIA-Pacific International Conference of Synthetic Aperture Radar APSAR, Seoul, Republic of Korea, September 26-30, ISBN: 978-899-3246-17-9. 
Reid, D.B. 1979. An algorithm for tracking multiple targets. IEEE Transaction on Automatic Control, 24(6), pp.843-854. Available at: https://doi.org/10.1109/TAC.1979.1102177.

Song, T.L., Mušicki, D., Kim, D.S., \& Radosavljević, Z. 2012. Gaussian mixtures in multi-target tracking: a look at Gaussian mixture probability hypothesis density and integrated track splitting. IET Radar, Sonar and Navigation, 6(5), pp.359-364. Available at: https://doi.org/10.1049/ietrsn.2011.0263.

Valdés, R.M.A., Comendador, V.F.G., Sanz, L.P. \& Sanz, A.R. 2018. Prediction of aircraft safety incidents using Bayesian inference and hierarchical structures. Safety science, 104(April), pp.216-230. Available at: https://doi.org/10.1016/j.ssci.2018.01.008.

\section{ПРОГНОЗ ВОЗМОЖНОСТИ СТОЛКНОВЕНИЯ ВОЗДУШНЫХ СУДОВ НА ОСНОВЕ БИНОМИАЛЬНОГО РАСПРЕДЕЛЕНИЯ}

Звонко М. Радосавлевич ${ }^{\text {, корреспондент, Бранко Д. Ковачевич }}{ }^{\text {, }}$ Деян С. Ивкович

а Военно-технический институт, г. Белград, Республика Сербия,

б Белградский университет, Электротехнический фракультет,

г. Белград, Республика Сербия

РУБРИКА ГРНТИ: 27.43.00 Теория вероятностей и математическая статистика,

28.15.00 Теория систем автоматического управления

78.21.49 Военная электроника и кибернетика

ВИД СТАТЬИ: оригинальная научная статья

ЯЗЫК СТАТЬИ: английский

Резюме

Введение/цель: На основе биномиального распределения функции плотности вероятности в данной статье представлена новая вероятностная модель для прогнозирования местоположения самолета.

методы: Предложенный алгоритм состоит из трех составляющих: сбор данных, мониторинг / оценка гибридного состояния и расчет вероятности столкновения. Информация о текущем местоположении и траектории полета используется для получения алгоритма предупреждения возможности столкновения между воздушными судами. Прогнозирование ситуаций, в которых воздушное судно может приблизиться $к$ другому на большом расстоянии, рассчитывается с высокой вероятностью. Оценка позиции и неопределенность относятся к идентифрикации данных целей, когда две траектории попадают в "окно» валидации с использованием фильтра идентификации данных по вероятности. 
Результаты: Разработан и протестирован эфрфективный алгоритм для предупреждения столкновений при сопровождении групповой цели.

Выводы: Результаты моделирования предотвращения столкновений самолетов, выполненного по двум сценариям траекторий подтверждают эфрфрективность предложенного алгоритма.

Ключевые слова: автоматическое управление, вероятность, отслеживание целей, идентификация данных.

\section{ПРЕДИКЦИЈА СУДАРА АВИОНА НА ОСНОВУ БИНОМНЕ} РАСПОДЕЛЕ

Звонко М. Радосављевић ${ }^{\mathrm{a}}$, аутор за преписку, Бранко Д. Ковачевић ${ }^{6}$, Дејан С. Ивковић ${ }^{\mathrm{a}}$

а Војнотехнички институт, Београд, Република Србија

б Универзитет у Београду, Електротехнички фракултет, Београд, Република Србија

ОБЛАСТ: математика, рачунарска техника, аутоматско управљање ВРСТА ЧЛАНКА: оригинални научни рад ЈЕЗИК ЧЛАНКА: енглески

\section{Сажетак:}

Увод/циљ: На основу биномне фуункције густине расподеле вероватноће, у овом раду је представљен нови вероватни модел предвиђања положаја ваздухоплова.

Meтоде: Предложени алгоритам састоји се од три различита блока: придруживање података, праћење/процена хибридног стања и израчунавање вероватноће судара. Информације о њиховим тренутним положајима и плановима лета користе се за добијање алгоритма за откривање могућих судара између ваздухоплова. Предвиђање ситуација у којима се ваздухоплов може приближити другом на већој удаљености израчунава се с великом вероватноћом. Процена положаја и неодређеност односе се на придруживање података циљева, када у „прозор” валидације падну два трага коришћењем фолтра са придруживањем података по вероватноћи.

Резултати: Дизајниран је ефрикасан алгоритам за откривање судара, који се тестира на многим вишеструким праћењима циљева.

Закључак: Резултати симулације превенције судара авиона у два сценарија путање потврђују ефикасност предложеног алгоритма.

Кључне речи: аутоматско управљање, вероватноћа, праћење циљева, придруживање података. 
Paper received on / Дата получения работы / Датум пријема чланка: 10.03.2020. Manuscript corrections submitted on / Дата получения исправленной версии работы / Датум достављања исправки рукописа: 26.04.2020

Paper accepted for publishing on / Дата окончательного согласования работы / Датум коначног прихватања чланка за објављивање: 27.04.2020.

(c) 2020 The Authors. Published by Vojnotehnički glasnik / Military Technical Courier

(www.vtg.mod.gov.rs, втг.мо.упр.срб). This article is an open access article distributed under the terms and conditions of the Creative Commons Attribution license (http://creativecommons.org/licenses/by/3.0/rs/).

() 2020 Авторы. Опубликовано в «Военно-технический вестник / Vojnotehnički glasnik / Military Technical Courier» (www.vtg.mod.gov.rs, втг.мо.упр.срб). Данная статья в открытом доступе и распространяется в соответствии с лицензией «Creative Commons» (http://creativecommons.org/licenses/by/3.0/rs/).

( 2020 Аутори. Објавио Војнотехнички гласник / Vojnotehnički glasnik / Military Technical Courier (www.vtg.mod.gov.rs, втг.мо.упр.срб). Ово је чланак отвореног приступа и дистрибуира се у складу са Creative Commons licencom (http://creativecommons.org/licenses/by/3.0/rs/).

(c) (i) 